\title{
Lean manufacturing as a High Performance Work System: the case of Cochlear
}

\begin{abstract}
This paper addresses the Special Issue call for Australian examples of innovative management systems that enable the production of successful products by drawing on a single case study: medical device manufacturer Cochlear. Through qualitative case study methodology we examine the human resource management practices that complemented the implementation of lean manufacturing principles. We argue that in their implementation, Cochlear's management team enriched the traditional understanding of lean and its focus on waste reduction, low cost and quality assurance by adopting people management practices as an integrated component of the overall management capability which allowed their people to grow and develop. The combination of lean and HR practices transformed Cochlear to a high performance work system and positively impacted production processes and output. By examining a medical device manufacturer, an under-researched sector, our paper expands existing literature on lean manufacturing and provides implications for practitioners.
\end{abstract}




\section{Introduction}

Over the past decade, Australia has seen a significant decline in productivity growth. According to a recent report by the Grattan Institute (2011), labour productivity for the Australian economy grew at an average of 1.5 per cent per annum over 2000-2010 compared with 2.1 per cent per annum over 1990-2000. This downward trend has triggered a debate in government, industry and academic circles, with stakeholders devoting time and resources in attempts to unearth the reasons behind such an alarming trend (see for example Green, Toner and Agarwal, 2012). The manufacturing industry features prominently in this debate, as it employs just under one million workers in Australia (Creighton, 2012) and as such makes "a substantial contribution to output, employment, productivity, exports, and hence economic growth" (Green et al., 2009, p. 10). A recent report released by the Prime Minister's Manufacturing Taskforce (Department of Innovation, Industry, Science and Research, 2012) sees Australia's future tied to manufacturing as that makes large direct and indirect contributions to national output, employment, investment and innovation. However, recently Australia's manufacturing capacity has been in decline, especially in the automotive sector, with Samson and Gloet (2013) highlighting that imports from China and elsewhere are increasing partly due to the high Australian dollar and relatively high wages. These pressures have placed manufacturers at a critical juncture, necessitating significant improvements in their management practices to ensure adaptation and thus, long-term survival.

This paper investigates Cochlear, a medical device manufacturer based in Sydney, Australia and answers the following key research question: how do HR practices and lean manufacturing impact organisational performance? To answer, we draw on interviews and focus groups conducted in 2009 and 2012 with management and employees to argue that carefully designed and implemented HR practices can complement lean manufacturing, thus transforming an organisation to a high performance work system and positively impacting production processes and output. The HR practices illustrated in this paper in combination with operational changes saw Cochlear's productivity more than quadruple: from a daily production of thirty-five electrodes in 2006 to 120 electrodes in 2009 to 150 in 2012. This impressive improvement, we argue, is partly due to a strong HR department which is not viewed as a support unit but as a value adding function in the organisation.

Methodologically, we treat Cochlear as an intrinsic case; in other words, our purpose in this paper is not theory building or "to understand some abstract or generic phenomenon" (Stake, 2005, p. 445) but to demonstrate the particular organisation "in all its particularity and 
ordinariness" (Stake, 2005, p. 445). Cochlear is undoubtedly a world-leader in their field, capturing approximately seventy per cent of the market share. Alongside ResMed and CSL, it is one of the few Australian companies that are successful on an international stage, with their culture of innovation heralded as a benchmark that other Australian companies should strive for (Smith, 2013). While choosing to study a unique case has been criticised by scholars who adopt a positivist paradigm because it cannot meet traditional "scientific" standards of generalisation, qualitative researchers have vehemently argued that the overwhelming commitment to generalise or theorize damages scholarly inquiry (Flyvbjerg, 2006; Stake, 2005) and can be 'inimical to the very nature of the case study enterprise' (Ruddin, 2006, p. 798). Thus, while Green et al. (2009) in a recent study of the management practices adopted in Australian manufacturing firms found that Australian organisations lag behind in their adoption of best practice in HR, our case study seeks to provide an example to the contrary.

Accordingly, we wish to clarify that we do not adopt a 'best practice' perspective by arguing that some management practices are 'universally' superior to others, hence adopting them will guarantee superior organisational performance. The notion of 'best practice' has a long historical lineage in management literature, with Frederick Taylor (1911, p. 25) asserting that "among the various methods and implements used in each element of each trade, there is always one method and one implement which is quicker and better than any of the rest". However, the assumption of 'one size fits all' has been widely criticized in management literature, as it fails to take into consideration the unique context each organisation faces. As such, whilst we wish to present Cochlear as a unique case study, we are cognizant that there is no 'one best way' to manage.

The structure of this paper is the following. First, we present a literature review of High Performance Work Systems. Second, we present the methodology adopted combined with the company profile and a brief historical context. We then continue to present our empirical data, gained through qualitative case study methodology drawing on five in-depth interviews and seven focus groups conducted with employees of various levels in the organisation (from the CEO to operators on the line), to shed much light into what makes Cochlear successful. We continue with the discussion of our findings and conclude the paper by highlighting the implications for scholarship, other Australian manufacturers and government policy.

\section{Lean Manufacturing as a High Performance Work System}


The notion of High Performance Work Systems arose largely as a response to the impact of work practices in manufacturing plants in the West (Applebaum, Bailey, Berg and Kalleberg, 2000; Boxall and Macky, 2007) which were highly criticised in the 1970s for deskilling production workers (Braverman, 1974). While scholars had been examining the effect and sources of motivation in the workplace since the highly influential Hawthorne studies (Roethlisberger, Dickson and Wright, 1939), management only began to take the "social aspect" of work seriously in the 1970s and 1980s with the rise of Japan as the manufacturing competitor to the US (Boxall and Macky, 2007). Within that context, struggling firms in the West re-examined their internal operations and adopted lean manufacturing practices which were born in Japan in the 1940s and are underpinned by three principles: value identification; waste elimination and; the generation of flow of value to the customer (Melton, 2005; Pakdill and Leonard, 2005). Lean manufacturing practices are now synonymous with "good manufacturing practices". For example, in the largest study of manufacturing practices in the world, Bloom and van Reenen (2007) define good practices in operations management as those practices that revolve around the implementation of modern and lean manufacturing techniques, such as Just-in-Time (JIT), Kanban (scheduling system for replenishment), 5S (method of organising and driving workplace efficiency), Enterprise Resource Planning (ERP) and others, that help improve efficiency, quality and flexibility in manufacturing firms (also Belekoukias, Garza-Reyes and Kumar, 2014; Bozer and Ciemnoczolowski, 2014; Ciemnoczolowski and Bozer, 2014). Lean manufacturing practices have been shown to improve inventory turnover and efficiency (Demeter and Matsuyz, 2011) thus enhancing operational and supply chain performance (White, Ojha, and Kuo, 2010; Flynn and Flynn, 2005) and financial performance (Hofer, Eroglu, and Hofer, 2012; Hsu et al., 2009). Implementation of lean practices helps standardize operations (Linderman, 2008; Naveh, 2004) and results in significant strategic benefits (Wadell and Bodek, 2005; Gonzalez-Benito and Gonzalez-Benito, 2008). According to Pakdill and Leonard (2014, p. 2) lean production methods provide manufacturing organisations with a powerful competitive advantage due to efficient systems that "consume fewer resources, creating higher quality and lower cost as outcomes". A similar argument is made by Belekoukias et al. (2014), who point to the operational improvements and resulting higher performance outcomes that lean techniques offer manufacturing organisations in contemporary globalised and highly competitive markets. 
Lean manufacturing principles do not only concern a company's technical operations but also its people. The adoption of lean saw companies move away from Tayloristic principles that encouraged the separation of "thinking from doing" through centralising decision-making at the top of the organisational pyramid. On the contrary, lean manufacturing argues for the involvement of production workers in decision-making through quality circles or other types of problem-solving groups and for raising their skills through training. Previous research has emphasised the importance of people in the successful implementation of lean: for example, Bhasin and Burcher (2006) drawing on literature on lean philosophy (e.g. Allen, 1997; Philips, 2002), argue that communication, teamwork and leadership are constant debates for a lean organisation to have, and a lack of those would lead to the failure of the lean system. Communication is highlighted as paramount in this regard, with Utley, Westbrook and Turner (1997, cited in Bhasin and Burcher, 2006, p 65) recommending a change of focus "from controlling to helping; from evaluating to empowering; from directing to coaching; and from planning to listening". As such, strategic human resource management becomes critical for lean practices to work (Pakdill and Leonard, 2014), a point made as early as 1995 when Forrester highlighted the role that HR practitioners could play in ensuring synergy between lean and people practices: "The whole process becomes a more people-centred one, with employees becoming more involved and flexible. In its simplest terms lean production has to be a people-driven process, because only the employees can identify ways of improving the existing process or product" $(1995, \mathrm{p} 22)$.

Some commentators (for example Applebaum et al., 2000) called these new work systems High Performance Work Systems (HPWSs). While there are various definitions of HPWS as well as other acronyms that are used interchangeably (for instance High Involvement Management (HIM), High Involvement Work Systems (HIWSs) and High Commitment Management (HCM)), the core of HPWSs in manufacturing is that "work is organised to permit front line workers to participate in decisions that alter organisational routines" (Applebaum et al., 2000, p. 7). Thus, while lean manufacturing and HPWS are certainly not synonymous, they both emphasise people management. HR academics have been arguing for over a decade that adopting HPWS principles and practices leads to higher organisational performance (e.g. Bailey et al., 2001; Becker and Gerhart, 1996; Gittell et al., 2010; Huselid, 1995; Ichniowski et al., 1996; Ramsey et al., 2000). Patterson, West, Lawthom and Nickell (1997) in a study conducted through the Institute of Personnel and Development in the UK found that there is a strong correlation between HRM practices and organisational 
profitability and productivity. In their report the authors emphasised the importance of selection, induction, training and appraisal as the most significant factors. HRM practices have also been found to explain performance differences in airlines (Gittell, 2001), high tech firms (Collins and Clark, 2003), call centres (Batt, 1999), steel-finishing lines (Ichniniowski et al., 1997), and banks (Richard and Johnson, 2004). However, the exact process through which HPWS practices contribute to organisational performance is a matter of debate with scholars now starting to explore the variables that mediate their relationship. For example, Evans and Davis (2005) argued that the relationship is mediated through internal social structures an argument shared by Gitell et al. (2010) who highlighted interactions between employees as the mediator. On the other hand, Beltran-Martin et al. (2008) argue that human resource flexibility is the mediating factor. There are two caveats that need to be made here. First, scholars (e.g. Batt, 1999; Dunlop and Weil, 1996; Gollan and Davis, 1999; Ichniowski et al., 1997; MacDuffie, 1995) have maintained that it is not the individual HRM practices that lead to superior performance but their combined effect. Arthur (1994), for example, argues for the need to adopt coherent systems of practice so as to capture the complementarities among the different components of an HPWS. Second, for HPWS to function and reap the benefits it claims to result into, the HR function cannot be seen as peripheral but rather as a strategic partner (Ulrich, 1998).

Therefore, for lean manufacturing to succeed, it needs to invest in the Human Resource Management (HRM) practices that are highlighted as crucial in the HPWS literature, such as training, remuneration and self-managed teams (Applebaum et al., 2000; Gittell, Seidner and Wimbush, 2010; Pakdill and Leonard, 2014). Investment in training allows employees to develop firm-related competencies which can be of technical nature or softer-skills that will allow the employee to actively participate in decision-making and engage in team building (Applebaum et al., 2000; MacDuffie, 1995; Youndt et al., 1996; Beltran-Martin, Roca-Puig, Escrig-Tena and Bou-Llusar, 2008). These outcomes are better achieved in the context of self-managed work teams as these empower employees to work autonomously, have control over decisions traditionally reserved for managers (Manz \& Sims, 1987) and develop their problem-solving skills (Applebaum et al., 2000). In addition, performance-related remuneration, such as employee stock ownership and profit sharing, as well as non-monetary rewards such as giving challenging tasks to talented employees are encouraged in order to motivate employees both extrinsically and intrinsically and to give them the impetus to contribute to the success of the organisation (Beltran-Martin et al., 2008). Finally, 
communication with employees has also been heralded as an important element of HPWSs. According to Applebaum et al. (2000), employees in HPWSs are expected to be wellinformed about the organisation and understand customer needs, ability predicated on communication within and between hierarchical levels. Similarly, Evans and Davis (2005) argue that both vertical and horizontal communication channels are required in an HPWS so that employees have access to information and opportunities to express viewpoints. Communication can happen through numerous ways such as employee suggestion schemes, employee consultative committees and suggestion boxes so that employees have the opportunity to express their opinions about the company and its management (del Brio, Junquera and Ordiz, 2008).

While people issues in the context of lean manufacturing have been examined extensively in the car industry (e.g. Adler, 1999; Babson, 1995; Lewchuk and Robertson, 1996, 1997; Lewchuk et al., 2001) scholars have pointed out that the applicability of lean principles, including relevant HR practices, has not been examined to the same extent in other sectors, such as health care (Hines, Holweg and Rich, 2004) and medical device manufacturing (Brown, Eatock, Dixon, Meenan, and Anderson, 2008; Eatock, Dixon and Young, 2009). In fact, Tortorella and Fogliatto (2014) maintain that while scholars agree on the importance of HRM practices for lean implementation, little attention has been paid to those. Even less academic research has been conducted on medical manufacturers partly because the sector is relatively new and highly fragmented with most organisations falling into the Small-Medium category (Santos, 2013). Thus, our paper seeks to add to this limited literature by examining the integration of lean production with HR practices in one of the most successful Australian medical manufacturers.

The remainder of this paper presents how Cochlear dealt with training, remuneration and communication practices in a consistent way that enabled their direct manufacturing operators to engage with the adoption of lean manufacturing. Before we do so, we present the company profile and the methodology we followed.

\section{Company profile and Methodology}

Cochlear is an Australian medical manufacturer, headquartered in Sydney, engaged in the production of devices for the hearing impaired. Their primary products are cochlear implants, which are a system of electronic components and software that are surgically inserted in the patient's mastoid bone. The patient wears an external speech processor which converts 
speech into a code of electrical impulses. This code is then transmitted to the implant via radio waves which also power the implant. The implant is connected to an array of electrodes that stimulate the cochlear nerve within the ear and the brain perceives these electrical impulses as sound. To produce a cochlear implant, six processes are followed: welding, moulding, helix, sort, cleaning and inspection (Senior VPHR).

Cochlear's manufacturing facilities are in Sydney and Brisbane, but there is also a smaller production plant in Sweden. In 2009, Cochlear had 1,888 employees and contractors worldwide, with 320 people employed in manufacturing in Sydney. In 2012, the company had grown to 2,390 people worldwide with 450 employed in manufacturing in Sydney. By all accounts Cochlear is a world leader in their field. The company retains approximately seventy per cent of the worldwide market-share and historically it has been growing at a rate of approximately fifteen per cent per annum (Annual report, 2009).

The primary sources of data for this case study included five semi-structured interviews and seven focus groups, which were conducted with Cochlear's staff members in the second half of 2009 (see table 1 for participants). Overall, we interviewed 26 individuals, with six being members of the leadership team and the rest engaged in production at various hierarchical levels (from team members to production engineers). We followed purposive sampling logic and identified individuals who could answer our questions; hence besides the CEO and the VPHR, the remaining employees and managers interviewed were directly engaged with the manufacturing department. Specifically, the employees were all employed in the production of electrode units, which is one of the three components of the Cochlear implant. Furthermore, in August 2012 we interviewed the Senior VPHR for a second time, so as to get an update about HR practices in Cochlear.

\section{- $\quad$ INSERT TABLE 1 PARTICIPANT PROFILE HERE -}

Traditionally, to judge the quality of research, scholars use the concepts of reliability and validity: the former refers to the stability of findings, the latter the truthfulness of findings (Silverman, 2011). While scholars are yet to agree on whether claims about reliability and validity can be made - or even, should be made - when evaluating qualitative research, we draw on Hammersley's (1990) criteria for judging case studies: plausibility; credibility; relevance. Plausibility asks whether a claim made for the case organisation is plausible; credibility whether the claim is based on evidence and; relevance whether the claim is relevant for knowledge. Similarly, Silverman (2011) argues that qualitative researchers 
should extensively document and report on their research strategy and analytical process to address concerns of reliability while drawing on analytical techniques identified in grounded theory such as constant comparison and deviant case analysis (Glaser and Strauss, 1967), to address concerns about validity.

The interviews and the focus groups took place in Cochlear's offices and lasted from thirty minutes to one and a half hours. Interviews and focus groups were recorded and transcribed verbatim and the data was coded using NVIVO. When coding, researchers look for significant themes in the text such as repetitions, metaphors and analogies, similarities and differences between participants' claims as well as missing data or silences about topics that were expected to come up given the topic of discussion (Ryan and Bernard, 2003). However, it is pertinent to note that the coding process was not linear but highly iterative as we moved back and forth main categories and subcategories.

The research team started the data analysis with open coding which involves fragmenting the text (by line, by sentence or even by paragraph) and giving each data fragment a name. The fundamental tool of open coding is constant comparison (Corbin and Strauss, 2008). The open codes were subsequently grouped into concepts that related to same phenomenon: these became our substantive categories (Locke, 2001) (see Figure 1):

\section{- INSERT FIGURE 1 EXAMPLE OF CODING HERE -}

In this case, during open coding we clustered employees' responses under Employee Consultative Committee (ECC) or team meetings. For example, the code team meetings included any reference interviewees made to the informal, five-minute meetings that happen at the beginning of each shift where the day's tasks are discussed and last day's problems are explained. Similarly, the code Employee Consultative Committee includes references interviewees made to the ECC (see below) such as the topics discussed as well as how the ECC reps are selected. Later, we categorised these open codes to formal and informal types of communication, the former encompassing formally set institutions and the latter 'the day-today relations between supervisors and subordinates' (Heller et al., 1998, p. 15).

In addition, we utilised data triangulation 'explicitly searching for as many different data sources as possible' (Denzin 2009, p. 301). Thus, supplementary material was reviewed, which was either publicly available or provided to us by the company's management. Table 2 below details the supplementary material reviewed: 


\section{- $\quad$ INSERT TABLE 2 ADDITIONAL MATERIAL REVIEWED HERE -}

\section{Results}

This section will present the findings from the focus groups and interviews we conducted. We begin by briefly presenting the context and Cochlear's shift to lean manufacturing and continue with a presentation of the following HR practices: training \& upskilling of staff; performance appraisal and remuneration; formal and informal communication. Our interpretation is supported by quotes from our interviewees, supplementary material listed above as well as publicly available information such as newspaper articles.

\section{Context: The shift to lean manufacturing and the introduction of teams}

In January 2006, Cochlear embarked on a significant change of their production system to be redesigned under lean manufacturing principles. The primary reason that led to the adoption of lean was the fact that Cochlear could not keep up with the growth in their business (Head of Manufacturing and Logistics ${ }^{1}$ ) under the previous batch production system, in which each individual operator was responsible for an implant from start to finish. The implementation of lean at Cochlear was initially treated with scepticism from employees, as it was believed that "they were going to ask us for more (output)" (team leader). However, this perception largely changed by the time of our interviews in 2009 and the employees we talked to preferred the lean manufacturing system as it allowed them to be more efficient in the production line.

The Head of M\&L argued that the previous work mode fostered an individualistic work culture. As such, the first change that preceded lean practices in Cochlear was a reorganization from silo based operations to 'businesses within the business' (internal presentation). Operators were reorganized in smaller teams of eight instead of larger groups of forty and were cross trained to perform all tasks within the team (team member; Head of M\&L). Figure 2 depicts manufacturing operations pre and post the implementation of lean:

\section{- INSERT FIGURE 2 STRUCTURAL CHANGES HERE -}

Challis, Samson and Lawson (2005) argue that investment in teams improves performance by giving employees a greater sense of ownership, increasing communication and increasing participation in decision making. Verifying such claims, reorganising the production line to

\footnotetext{
${ }^{1}$ Henceforth, M\&L
} 
smaller teams led to significant benefits for Cochlear, especially with regards to solving problems on the production line. In the interviews, the enhanced ability to problem-solve was attributed to enhanced communication "between team members, between team members and team leaders, between team leaders and production managers" (production manager). In fact according to the Senior VP (Manufacturing), the reorganisation allowed team leaders to interact directly with the production engineers resulting in a significant exchange of knowledge and "in problems being solved by team leaders and team members when [before] everything used to go to an engineer". The same interviewee also mentioned that at the time, Cochlear was just starting to implement a Kaizen process whereby a team that was faced with a particular challenge or identified an opportunity for improvement "they might stop for a week, take that problem, work together on how they can solve it". Production engineers interviewed also agreed that problem solving was enhanced due to increased communication on the production floor. However, they went even further to argue that adopting staff suggestions was a mechanism for empowerment: "like all of us they [team leaders] like the attention. They like that you're coming to them for information, that you don't presume to know more than them, that you're saying: I need your experience to help us".

Needless to say, Cochlear did not rely solely on communication for problem solving, but put in place numerous checkpoints to ensure that product failures are kept to a minimum - such as introducing technology which measures hourly output, failures, machine breakdown and so on. Importantly, this IT system links an operation to a particular individual which ensures accountability and speeds up problem solving. Team members explained: "it's really upsetting because we spend nearly one hour on a job and then [the electrode] is a reject and we really, really want to find out why".

As a result of these changes, production grew 95 per cent in five years, and yield increased from 67 per cent to 87 per cent (internal presentation). The Head of M\&L was particularly proud of these achievements: “[with lean] we've come from a department that stops the organisation from growing, holds the organisation back, to a department, now, that is taking a much bigger role to the achieving of the organisational strategy'

\section{Training and upskilling of staff}

Conceptually, HPWSs draw on the Resource Based View of the firm (RBV) (Barney, 1991) which advocates functional flexibility in the workforce; in other words, employees are expected to be able to complete numerous diverse tasks under diverse circumstances or they 
are able to learn how to perform new tasks quickly (Wright \& Snell, 1998). According to Beltran-Martin et al. (2008), functional flexibility also assumes that the cost of reassigning employees into new roles is low.

Flexibility is taken quite seriously in Cochlear. As part of the lean implementation and to allow the management of operators' training needs as well as the management of their performance, the HR team in Cochlear under the leadership of the Senior VPHR, put together a classification matrix which

...lists all operations and all members in a team and plots each member's competency against each operation. So let's say we have 10 operations in that area and we've got 10 people in the team. That equals to 100 training opportunities. If we've covered 40 of those training opportunities means we're operating at $40 \%$ flexibility - which means that $60 \%$ is the training gap... The idea is to get as close to $100 \%$ as possible but that's quite theoretical... But we try to reduce the training gap as much as possible... (HR professional, M\&L).

Each team has their own matrix and for each operation there are four levels of competence (from novice to proficient). The idea behind the classification matrix is that all individuals within a team can perform all operations (Head of M\&L). Each team's classification matrix is available to all members in the team as well as visible to everyone through a training board, thus encouraging transparency and allowing operators to take ownership of their career progression (HR professional M\&L). The classification matrix enables team members to apply for promotion by progressing through assessment steps, and allows team leaders to know "where skills are in their team and where the risk areas are" (HR professional, M\&L). Organisationally, the purpose of the matrix was to "build flexibility within the team and remove business risk" (HR professional, M\&L).

This flexibility was demonstrated in a rather dramatic fashion in September 2011, when Cochlear initiated a voluntary recall of their latest implant - the CI 500 range - alarmed by increasing number of reported failures. The device made up more than fifty per cent of Cochlear's sales surmounting to over 800 million dollars. The recall was deemed voluntary because the devices had not caused injury to any patients but had simply failed (Ahmed 2011). The Senior VPHR explained that management initiated the recall because they did not want to risk the company's reputation with more device failures. The Head of M\&L (personal communication, 2011) recalls: "On the Friday we all went home, on the Monday we had to 
move people from making one product to making something completely different...so we had a meeting with manufacturing employees and explained to them what the impact of the recall was going to be ... and the way they responded was superb.... It's actually been a lesson for me... helped me realise how flexible we've actually become".

Training at Cochlear did not only cover operational flexibility. In our 2009 interview, the Senior VPHR explained that Cochlear sent their team leaders on a Competitive Manufacturing course ran by the New South Wales Technical And Further Education Commision (TAFE NSW), Australia's leading vocational education and training provider. The course - now renamed Competitive Systems and Practices (https://www.tafensw.edu.au/howex/servlet/Course?Command=GetCourse\&CourseNo=1142 6) accredited participants with a Certificate IV which is the highest level of qualification TAFE provides. The program taught team leaders principles of "continuous improvement" (team leader) and "people management" (team leader). The rationale for enrolling team leaders in the Competitive Manufacturing course was that three years after the implementation of lean principles team leaders were preoccupied with leadership work 'they can lead change within their teams' as opposed to technical "fire fighting" '(HR Professional M\&L).

In addition, and due to the high proportion of migrant workers employed, Cochlear initiated an English-language training program entitled WELL (Well Placed English Language Speakers). A climate survey conducted in 2006 showed that employees spoke languages other than English in the workplace, which was problematic for management as "operators were unable to understand technical work instructions and terminology" (Senior VPHR). Given the strict regulatory framework Cochlear operates under, "the main driver was to make sure there's open communication and a common standard that everyone follows within the team" (Senior VPHR). The WELL program was thus initiated and "in the first year we had about 200 people participate" (HR professional, M\&L). Cochlear continued to fund the program even after the government grant that initially paid for it was exhausted; even more importantly, staff were paid overtime to participate in the program (team leader). The primary benefit reported from this program was increased confidence: "most people who have gone through the program have come back and said we feel more confident now standing up and talking to our teams and our team leaders compared to before' (HR professional, M\&L).

In our follow up interview, we asked if the WELL program was still continuing and indeed it was in the Brisbane operations as the Sydney contingent had already gone through it: "...in 
the selection process we're hiring people with much more (sic) English competence. So that particular program isn't necessarily what we have to invest in anymore" (Senior VPHR).

\section{Performance appraisal and remuneration}

In discussing remuneration practices in HPWSs, Pfeffer (1998) argued that these firms pay above market wage so as to increase commitment to the organisation's goals. This is true for Cochlear employees who are paid forty five per cent above award wages (Hannan and Warne-Smith 2009). Further, in compliance with the theory on HPWSs, Cochlear uses employee and executive share option plans. Moreover, level 3 staff and above are entitled to short-term incentive program; eighty per cent of that bonus is based on company performance and twenty per cent on individual performance as measured through the biannual Performance Development Review (PDR). The PDR in Cochlear is compulsory for all staff from a team leader level and above and assesses both performance and behaviours. It works on a five-level scale 'both for performance and for behaviours...how you achieved those objectives, how you delivered those objectives' (Senior VP M\&L). While the bonus is primarily calculated on performance, if the desired behaviour is not exhibited, then the employee will not get it (Senior VPM\&L).

The incentives described above are not available to production employees. Nonetheless, according to the Senior VP M\&L team members and team leaders are eligible for a quarterly bonus. The Head of M\&L explained that a weekly audit is performed on a team level to determine eligibility for the bonus. The audit examines "teamwork, housekeeping, workplace organisation philosophy and standardisation of the workplace" (production manager). The rationale behind the bonus being based on the above instead of productivity improvements is that the criteria are within employees' control: "they might not have control over supply of parts or equipment breakdowns and things like that" (Head of M\&L). However, the extent to which this rationale was understood by employees is debateable as production managers claimed that "as long as you do your job you get it" (production manager). As such, at the time of the interviews a production manager highlighted that because everyone gets the quarterly bonus "it has become an expectation as opposed to an incentive".

Non-financial rewards are not particularly popular in Cochlear. The Senior VP (M\&L) maintained that top performers are "recognised" either weekly or bi-weekly with "a round of applause in a meeting”. Production staff interviewed spoke highly of the annual Christmas party and the annual Ping-Pong competition and the Senior VP (M\&L) mentioned that for 
every five years of service team members get a plaque and a voucher from a popular department store. When asked as to why non-monetary rewards are not used more extensively, production managers claimed that singling out individuals would go against the cultural value of "fairness" that is prevalent in Cochlear. Also, because performance on the line is measured on a team level isolating individual performers is difficult: "the feedback comes back very quickly. What about us?" (production manager).

\section{Formal and informal communication}

In accordance with the literature on HPWS and lean manufacturing, communication in Cochlear is of paramount importance and happens both formally and informally. Formally, communication between managers and employees happens primarily through the Employee Consultative Committee (ECC) which was constituted in 2005 and was included in the Enterprise Partnership Agreement signed between Cochlear and the Australian Manufacturing Workers Union (AMWU). The ECC is comprised by an equal number of employees and management representatives and is used as a means to discuss matters of importance with employees, such as the adoption of flexible working arrangements, production targets and training opportunities. The consultative committee coordinates the production teams within Cochlear and provides data "to those teams and information which may be relevant to the undertakings and performance of the teams" (Industrial Relations Commission of New South Wales 2005, p. 15). Finally, the committee contributes to dispute resolution and "any issue of relevance to the operations of Cochlear, or of the employees ... with no reasonable limit placed on the agenda for such consideration" (Industrial Relations Commission of New South Wales, 2005).

In 2009, the ECC had twelve members: it was chaired by the four production managers, and attended by the occupational health and safety manager and the Head of M\&L (HR Manager, M\&L). There were six employee representatives who were nominated by their peers (ECC member). As it currently stands, the ECC has nine employee representatives for a three year term and includes shift supervisors, a new hierarchical level introduced to cope with the increasing demand for the product. Cochlear provides training to the employee representatives, which includes an understanding of the topics appropriate to be raised in the ECC context. For example, the HR Manager (M\&L) was adamant that the ECC is not the appropriate context to discuss problems with specific individuals in a shift and/or area. In 2009 , the committee was meeting once a month for two hours; however in 2012 , due to the 
product recall, this meeting was shortened to one hour a month. Employee representatives are paid overtime to attend, if the forthcoming scheduled meeting is not in their shift.

While the majority of the ECC meetings focused on the social aspect of work (Taras and Kaufman, 2006) such as the Ping-Pong competition, lunch room cleanliness and provisions, and parking, some issues of substance were discussed the most prominent being changes to the classification matrix. In 2009, the HR Manager (M\&L) recalled that concerns were brought to management via the ECC about Time To Proficiency (TTP), the point system used for staff accreditation, not matching the actual requirements of the job and resulting in dissatisfaction among manufacturing staff. As a result, the classification matrix changed to recognise those processes that are more complex. The HR Manager (M\&L) highlighted this was a particularly successful outcome, and as a result, the issue of accreditation was being further explored with other production areas, though, not through the ECC but through focus groups. In 2012 topics were largely the same, with the addition of employee shares and the employee bonus scheme (in terms of its timing).

To ensure that Cochlear employees are aware of the issues discussed in the ECC, copies of the minutes are provided in the lunchroom. Moreover, each employee rep personally informs his/her team/ area in the weekly team meeting that follow the ECC meeting. The ECC members we interviewed took a lot of pride in their role and saw themselves as the voice of workers: "we are the voice [of workers]. We are the messengers. So I am really proud to be in the ECC because it's good for us... It's also good for the company. Otherwise, if we don't have a committee, then we don't know what's really going on" (ECC member). On the other hand, in our 2009 interview the Head of M\&L was critical of the ECC arguing that the focus on "parties and barbeques" did not capture substantive issues regarding everyday work on the line, including concerns about certain team leaders showing favouritism to some operators, thus disadvantaging others. However, he claimed that the reason behind the emphasis given on such "silly" issues was that "our employees are generally happy".

In addition to the ECC and in their effort to give voice to staff who "are not comfortable going to the rep or for people who are shy, don't feel comfortable with their level of English" (Senior VPHR), Cochlear utilised a suggestions box in 2009. However, three years later the suggestions box is not used as much because of its location:

When asking people about the box they advised me that they felt it was too open and if people saw them putting suggestions in there they were challenged about what was put in 
there. Most people I have spoken to are comfortable speaking with their ECC representatives directly though so we don't feel that topics are being missed despite the box not really being used (HR rep M\&L, personal communication).

In 2009, the Head of M\&L took measures to ensure that complaints regarding the team leaders that were not captured by the ECC were heard: "I'm running these focus groups. So I sit down with 10 people at a time, 320 of them, so I have to do 32 sessions ... I am trying to find out what is going on, because they won't necessarily bring it to the ECC". These focus groups were not continuing in 2012; however, Cochlear runs engagement surveys on a biennial basis, where employees are given the opportunity to voice any concerns they have, such as team leaders' skills, in the open ended questions asked. Finally, the Senior VP Manufacturing runs monthly communication meetings and ad hoc meetings have taken place in the lunch room to update employees on issues of importance.

\section{Discussion}

Our paper has presented HRM practices adopted in Cochlear, a highly successful Australian medical device manufacturer. The practices described above, in combination with operational changes that were taken up as part of the change to lean manufacturing, transformed Cochlear to a High Performance Work System and saw the company's productivity more than quadruple: from a daily production of thirty-five electrodes in 2006, to 120 electrodes in 2009 and to 150 in 2012.

The case study evidence presented in this paper highlights a number of issues regarding a manufacturing company's implementation of lean and transition to a HPWS. First, the case study suggests that lean requires a change in the management of employees (Tortorella and Fogliatto, 2014) in that companies should communicate with, remunerate, train and equip shopfloor workers so that they have ownership of the production process (Gollan and Davis, 1999). West and Patterson (1998) suggest that encouraging employees on the lower hierarchical levels to manage their work enables them to recognise problems and generate solutions. The importance of discovering errors quickly, rectifying and learning from them is also emphasised by Weick and Sutcliffe (2007), who claim that establishing a culture where individuals are not afraid to speak up will make recovering from inevitable errors possible. As evidence demonstrated, Cochlear invested significantly in their production employees through operational training as well as English language training, and leadership skills training for team leaders. Confirming the literature, this investment led to increased problem 
solving from the direct operators and increased employee responsibility for departmental performance (see for example Challis et al., 2005).

Second, our case study shows the importance of HRM practices that not only complement the organisational strategy but are consistent with each other. Our argument is that Cochlear understood the importance of viewing and adopting lean practices as a cultural change and proactively acted to bring people along with them during this period of change, instead of imposing lean practices on them, as is often the case. In Cochlear, the HRM practices were designed to facilitate the transition to lean but as importantly, to reinforce the importance that manufacturing operators make for the company's success. Thus, employees are kept informed, are extensively trained and are highly remunerated. Potentially, Cochlear has no other choice, as their production process is still highly manual due to the dexterity required to produce an implant. Regardless of the motivation though, the fact of a successful implementation of lean philosophy companywide with impressive results remains.

Third, Cochlear's approach to the introduction of lean manufacturing coupled with investment on and communication with employees allowed them to overcome resistance to the rather radical change to their operations. Research has shown the detrimental effects on organisational change initiatives that do not involve some form of employee consultation; for example, Kotter (1996 p. 63) argued that "without credible communication, and lots of it, the hearts and minds of the troops are never captured". Similarly, Lewis, Schmisseur, Stephens and Weir (2006, p. 118) highlighted that change agents' principal role is to "promote communication and participation". While the authors recognise that management leads and controls organisational change efforts, they claim that "participation gives members a sense of control and reduces uncertainty about changing circumstances, such that if people can feel part of the implementation process, they will be more committed to the change" (p. 120).

\section{Implications for practice and policy}

In our mind, Cochlear's success was partly due to a strong HR department and it is here that we wish to draw practitioners' attention. In our interviews, we found that the HR department at Cochlear was not a support unit but that it was viewed as a value adding function in the organisation. In fact, the significance of the HR department for Cochlear's success was emphasised by the majority of our participants and was even a point of interest in our interview with the CEO who found it "surprising but quite pleasing" that people actually used HR. A development that facilitated the overwhelmingly positive view of HR was the 
establishment of an HR division in manufacturing. A maintenance engineer with over five years tenure in Cochlear recalls:

HR's role has certainly changed over the last few years. When I started here, HR... I knew all of their names and I could go in and say hello but really I didn't have any kind of real interaction with them other than dropping forms off. [It used to be that] manufacturing was way down the back and HR was right at the front, upstairs near the CEO. When we actually moved a couple of HR reps down here, I saw that as a massive turning point. That's where we had our own dedicated manufacturing people. Really, maybe 40 per cent of [Cochlear] people worked here but no one from HR ever went near them. To have that now, this regular interaction - we'd be talking to [HR rep name] and [HR rep name] at least a couple times a week, maybe more often than that. To have people here constantly offering you support, advice, assistance, I think is a huge difference... Distinctly I think the quality of the advice and the willingness to be involved is certainly there now. That wasn't there in the past... I think the implementation and the delivery have changed hugely in the last few years.

We view the move of HR representatives to manufacturing as a shift that signified that manufacturing operators were indeed significant for Cochlear and in our mind that was an important step in making employees feel valuable and improving trust levels between manufacturing operators and senior management. This is a move that many manufacturers, whether in Australia or overseas, can emulate. While we are cognizant of the costs, both monetary and in time, associated with the design and implementation of good HR practices, our case study shows that, in the long term, the benefits significantly outweigh these costs. It is important here to note that adopting lean practices can only be a long-term commitment if a company expects to see positive results from their efforts (Emiliani, 2003; Gregory, 2002; Liker, 2004).

There are additional implications for practitioners stemming from our paper. By highlighting that effective management is a key driver for performance, we wish to alert employers to the need to critically examine the practices followed in their firms. In 2009 Green et al. (p. 38) maintained that a number of Australian manufacturers are "unaware of their management standards and are operating under the false premise that their performance is better than it is". Our findings suggest the need for companies to develop coherent policies, systems and processes that complement and reinforce each other. In addition, our case study suggests that manufacturers should invest in their workforce while adopting operational requirements of 
lean practices. Further, and similarly to Green et al (2009) we argue that an empowered workforce leads to enhanced sense of accountability which in its turn leads to enhanced productivity. In doing so, manufacturers in Australia and elsewhere can not only enhance the productivity of their workforce and the profitability of their firm, but also lead the way in rebuilding the Australian manufacturing industry as a whole.

Obviously, adequate support from policy makers is required in this regard. As government examines and seeks to rectify the declining rates of Australian productivity, it should consider how to enhance labour market flexibility through an industrial relations system that emphasises collaboration between employers and employees. In addition, investing in education and skills for manufacturing workers is extremely important especially given the job losses that have been sustained over the past few years.

\section{Limitations and directions for future research}

Our paper is not without limitations. Our findings cannot be generalised as the data from a single case study is idiosyncratic and the insights generated often inapplicable to other organisations; to that end, we encourage researchers in the discipline to look for other organisations and through qualitative, longitudinal research achieve either literal or theoretical replication (Yin, 2003). However, our findings contribute to the limited literature on medical device manufacturing firms. Enhancing scholarly knowledge on this sector is significant, especially given the demise of traditional manufacturing in Australia: medical manufacturers have the ability to absorb skills from the automotive industry and add a new manufacturing and skills base through areas like nanotechnology and biomaterials (Williamson, 2013). To date, limited information exists on this sector and what does exist is limited to the grey literature (Eatock et al., 2009). This paper addresses the paucity of data by describing the HR practices that complemented lean operations in one of the most successful Australian manufacturers. In doing so our paper paves the way for theory building in the area. Specifically, although there is a wealth of knowledge about operational practices that contribute to productivity and technical innovation, our case study suggests that research on manufacturing would benefit from a people management lens. As importantly, our analysis suggests that researchers should examine the interdependencies between operations and people management practices as that leads to more nuanced understanding of the intricacies that make a manufacturer successful. Finally, given that Australia represents a large and highly advanced medical device market, we wish to urge researchers to explore other medical 
manufacturers and advance the limited knowledge that exists on this promising manufacturing sector.

\section{Conclusion}

This paper addresses the Special Issue call for Australian examples of innovative management systems that enable the production of successful products by drawing on a single case study: medical manufacturer Cochlear which is one of the few Australian firms successful on a global stage. We argued that the human resource management practices followed in the company combined with lean manufacturing principles, transformed Cochlear into a High Performance Work System. Through a qualitative case study we conclude that manufacturing organisations in Australia can learn much from Cochlear, in particular from its holistic approach to lean manufacturing. We argue that in their implementation, Cochlear's management team enriched the traditional understanding of lean and its focus on waste reduction, low cost and quality assurance by adopting people management practices as an integrated component of the overall management capability which allowed their people to grow and develop. It is to this people-centric philosophy in conjunction with lean operation that we attribute Cochlear's success. 


\section{References}

Adler J.S. 1999. Human resource management at two Toyota transplants. In J.K. Liker, W.M. Fruin and P.S. Adler (eds) Remade in America: Transplanting and transforming Japanese management systems. New York: Oxford University Press, pp 75-116

Ahmed, Nabila. 2011. Big risk in Cochlear's precautionary recall. The Australian, 13 September.

Allen, J.H. 1997. Lean and mean - workforce in America. Journal of Workplace Learning, vol. 9, pp. 1-6.

Applebaum, E., Bailey, T., Berg, P. and Kalleberg, A.L. 2000. Manufacturing advantage: why high-performance work systems pay off. Ithaca: Cornell University Press

Arthur, J. B. 1994. Effects of human resource systems on manufacturing performance and turnover. Academy of Management Journal, vol. 37, pp. 670-687.

Babson S. 1995. Lean work: empowerment and exploitation in the global auto industry. Detroit MI: Wayne State University Press

Bailey, T., P. Berg, and C. Sandy. 2001. The effect of high-performance work practices on employee earnings in the steel, apparel, and medical electronics and imaging industries. Industrial and Labor Relations Review, vol 54, pp. 525-544.

Barney, J. B. 1991. Firm resources and sustained competitive advantage. Journal of Management, 17, 99-120.

Batt, R. 1999. Work design, technology and performance in customer service and sales. Industrial and Labor Relations Review, vol. 52, pp. 539-564.

Becker, B., B. Gerhart. 1996. The impact of human resource management on organizational performance: Progress and prospects. Academy of Management Journal, vol 39, no 4, pp. 779-801.

Belekoukias, I., Garza-Reyes, J.A., and Kumar V. 2014. The impact of lean methods and tools on the operational performance of manufacturing organisations. International Journal of Production Research, DOI: 10.1080/00207543.2014.903348

Beltran-Martin, I., Roca-Puig, V., Escrig-Tena, A. and Bou-Llusar, J.C. 2008. Human resource flexibility as a mediating variable between high performance work systems and performance. Journal of Management, vol 34, no 5, pp 1009-1044 
Bhasin, S. and Burcher, P. 2006. Lean viewed as a philosophy. Journal of Manufacturing Technology Management, vol 17 (1), pp 56-72

Bloom, N., and Van Reenen, J., 2007. Measuring and explaining management practices across firms and countries. Quarterly Journal of Economics, CXXII, 1351-1408.

Boxall, P. and Macky, K. 2007. High-performance work systems and organisational performance: bridging theory and practice. Asia Pacific Journal of Human Resources, vol 45, no 3, pp. 261-270

Bozer, Y.A. and Ciemnoczolowski, D.D. 2013. Performance evaluation of small-batch container delivery systems used in lean manufacturing - Part 1: system stability and distribution of container starts. International Journal of Production Research, vol. 51, no. 2, pp: 555-567

Braverman, H. 1974. Labor and Monopoly Capital. NYU Press

Brown, A., Eatock, J., Dixon, D., Meenan, J. and Anderson, J. 2008. Quality and continuous improvement in medical device manufacturing. The TQM Magazine vol 20, no 6, pp 541-555

Challis, D., Samson, D. and Lawson, B. 2005. Impact of technological, organizational and human resource investments on employee and manufacturing performance: Australian and New Zealand evidence. International Journal of Production Research, vol 43, no 1, pp. 81107

Ciemnoczolowski, D.D. and Bozer, Y.A. 2013. Performance evaluation of small-batch container delivery systems used in lean manufacturing - Part 2: number of Kanban and workstation starvation. International Journal of Production Research, vol. 51, no. 2, pp: 568581

Collins, C. J., K. Clark. 2003. Strategic human resource practices, top management team social networks, and firm performance. Academy of Management Journal, vol. 46, pp. 740751.

Corbin, J. and Strauss, A. 2008. Basics of qualitative research. Third edition, Thousand Oaks, CA: Sage

Creighton, A. 2012, Productivity growth fastest in nine years, The Australian, June 12

Demeter, K., and Matsuyz, Z., 2011. The impact of lean practices on inventory turnover. International Journal of Production Economics, vol. 133, pp. 154-163. 
del Brio, J.A., Junquera, B. and Ordiz, M. 2008. Human resources in advanced environmental approaches - a case analysis, International Journal of Production Research, vol 46, no 21, pp: 6029-6053

Denzin, N. 2009. The research act: a theoretical introduction to sociological methods. New Jersey: Transaction Publishers

Department of Industry Innovation Science Research and Tertiary Education. 2012. Prime Minister's Manufacturing Taskforce - Report of the Non-Government Members. Canberra: Commonwealth of Australia.

Dunlop, J. T., and Weil, D. 1996. Diffusion and performance of modular production in the U.S. apparel industry. Industrial Relations, vol. 35, no. 3, pp. 334-355.

Eatock, J., Dixon, D. and Young, T. (2009) An exploratory survey of current practice in the medical device industry. Journal of Manufacturing Technology. Vol 20, no 2, pp. 218-234

Emiliani, B. 2003. Better Thinking, Better Results, CLBM, New York, NY.

Evans, W.R. and Davis, W.D. 2005. High-performance work systems and organizational performance: the mediating role of internal social structure. Journal of Management, vol 31, no 5 , pp. $758-775$

Flynn, B.B. and Flynn, E.J. 2005. Synergies between supply chain management and quality management: emerging implications, International Journal of Production Research, vol. 43 (16), pp. 3421-3436

Flyvbjerg, B. 2006. Five misunderstandings about case-study research. Qualitative Inquiry, vol 12, no 2, pp. 219-245

Forrester, R. 1995. Implications of lean manufacturing for human resource strategy. Work Study, vol 44 (3), pp 20-24

Gittell, J.H., Seidner, R. and Wimbush, J. 2010. A relational model of how high-performance work systems work. Organization Science, vol 21, no 2, pp 490-506

Glaser, B.G. and Strauss, A.L. 1967. The discovery of grounded theory: strategies for qualitative research. New Jersey: Transaction Publishers

Gollan, P.J. and Davis, E.M. 1999. High involvement management and organizational change: beyond rhetoric, Asia Pacific Journal of Human Resources, vol. 37, no. 3, pp. 69-91 
Gonzalez-Benito, J., and Gonzalez-Benito, O., 2008. Operations management practices linked to the adoption of ISO 14001: An empirical analysis of Spanish manufacturers. International Journal of Production Economics, vol. 113, pp. 60-73.

Green, R., Toner, P. \& Agarwal, R., 2012. Understanding Productivity - Australia's ChoiceThe McKell Institute and UTS Sydney joint publication, p. 1-59; released on Nov 12, 2012, http://mckellinstitute.org.au/understanding-productivity-australias-choice.

Green, R., Agarwal, R, Van Reenen, J., Bloom, N., Mathews, J., Boedker, C., Sampson, D., Gollan, P., Toner, P., Tan, H., Randhawa, K, Brown, P., 2009, Management Matters - Just how productive are we? - Report for the Department of Innovation, Industry, Science and

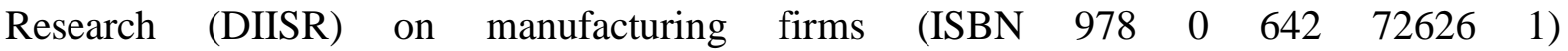
http://www.innovation.gov.au/Industry/ReportsandStudies/Documents/ManagementMattersin AustraliaReport.pdf accessed on 28 May 2012.

Gregory, A. 2002. Can lean save UK Manufacturing? Works Management, Vol. 55 No. 7, pp. $1-6$.

Hammersley M. 1990. Reading Ethnographic Research: A Critical Guide. Longman, London.

Hannan, E., and Warne-Smith, D. 2009. ACTU trumpets Cochlear victory. The Australian, 21 August 2009.

Heller F, Pusić E, Strauss G and Wilpert B. 1998. Organizational Participation: Myth and Reality, New York: Oxford University Press.

Hines, P. Holweg, M. and Rich, N. 2004. Learning to evolve: a review of contemporary lean thinking. International Journal of Operations and Production Management, vol 24, no 19, pp 994-1011

Hofer, C., Eroglu, C., and Hofer, A.R., 2012. The effect of lean production on financial performance: The mediating role of inventory leanness. International Journal of Production Economics (Article in press).

Hsu, C.C. Tan, K.C, Kannan, V.R, and Keong Leong, G (2009) Supply chain management practices as a mediator of the relationship between operations capability and firm performance, International Journal of Production Research, vol. 47 (3), pp. 835-855 
Huselid, M.A. 1995. The impact of human resource management practices on turnover, productivity and corporate financial performance. Academy of Management Journal, vol 38, no 3, pp. 635-672

Ichniowski, C., Shaw, K., \& Prennushi, G. 1997. The effects of human resource management practices on productivity: A study of steel finishing lines. American Economic Review, vol 87, pp. 291-313.

Ichniowski, C., T. Kochan, D. Levine, C. Olsen, G. Strauss. 1996. What works at work: Overview and assessment. Industrial Relations, vol 35, pp. 299-333.

Kotter, J.P. 1996. Leading change. Boston: Harvard Business School Press.

Lewchuk, W. and Robertson, D. 1996. Working conditions under lean production: a workerbased benchmarking study. In P. Stewart (ed) Beyond Japanese management: the end of modern times? London: Frank-Cass, pp 60-81

Lewchuk, W. and Robertson, D. 1997. Production without empowerment: work reorganisation from the perspective of motor vehicle workers. Capital Class, vol 63, pp. 37-65

Lewchuk, W, Stewart, P. and Yates, C. 2001. Quality of working life in the automobile industry: a Canada-UK comparative study. New Technology, Work and Employment, vol 16, pp. $72-87$

Lewis, L. K., Schmisseur, A. M., Stephens, K.K. and Weir, K. E. 2006. Advice on communicating during organizational change: the content of popular press books. Journal of Business Communication, vol 43, no 2, pp. 113-137.

Liker, J.K. 2004. The Toyota Way - 14 Management Principles from the World's Greatest Manufacturer. McGraw-Hill, New York, NY.

Linderman, K., 2008. Six sigma: definition and underlying theory. Journal of Operations Management, vol. 26 (4), pp. 536-554.

Locke, K. 2001. Grounded theory in management research. SAGE

MacDuffie, J, P., 1995. Human resource bundles and manufacturing performance: organization logic and flexible production systems in the world auto industry. Industrial and Labour Relations Review, vol. 48(2), pp. 197-221. 
Manz, C. C., and Sims, H. P. 1987. Leading workers to lead themselves: The external leadership of self-managing work teams. Administrative Science Quarterly, vol 32, pp.106128.

Melton, T. 2005. The benefits of lean manufacturing: what lean thinking has to offer the process industries. Chemical Engineering Research and Design, vol 83, no A6, pp 662-673

Naveh, E., Marcus, A., and Moon, H-K., 2004. Implementing ISO 9000: performance improvement by first or second movers, International Journal of Production Research, vol. 42(9), pp. 1843-1863

Pakdill, F., and Leonard, K.M. 2014 Criteria for a lean organisation: development of a lean assessment tool, International Journal of Production Research, DOI: $10.1080 / 00207543.2013 .879614$

Patterson, M., West, M., Lawthom, R., and Nickell, S. 1997 Impact of people management practices on business performance. Issues in People Management no. 22. London: Institute of Personnel and Development.

Pfeffer, J. 1998. The human equation. Boston: Harvard Business School Press.

Philips, E. 2002. Pros and cons of lean manufacturing. Forming and Fabricating, October, pp. 1-5.

Ramsey, H., D. Scholarios, B. Harley. 2000. Employees and high performance work systems: Testing inside the black box. British Journal of Industrial Relations, vol 38, pp.501-532.

Richard, O. C., N. B. Johnson. 2004. High performance work practices and human resource management effectiveness: Substitutes or complements? Journal of Business Strategy, vol. 21, no. 2, pp. 133-148.

Roethlisberger, F. J., Dickson, W. J. and Wright, H. A. 1939. Management and the worker, Cambridge, MA, Harvard, UP.

Ruddin, L.P. 2006. You can generalise stupid! Social scientists, Bent Flyvbjerg and Case study methodology. Qualitative Inquiry, vol 12, no 4, pp. 797-812

Samson, D. and Gloet, M. 2013. Innovation capability in Australian manufacturing organisations: an exploratory study. International Journal of Production Research. DOI: $10.1080 / 00207543.2013 .869368$ 
Santos, I.C.T. 2013. Product development methodologies: the case of medical devices. Unpublished thesis.

Silverman, D. 2011. Qualitative Research. Third Edition, London, SAGE

Smith, M. 2013. An ear for business and innovation. The Australian Financial Review, June 4 2013

Stake, R. 2005. Qualitative Case Studies. In Denzin, N.K and Y.S. Lincoln (eds). The SAGE Handbook of Qualitative Research, Third Edition, London, SAGE

Taras, D.G., and B.E. Kaufman. 2006. Non-union employee representation in North America: diversity, controversy and uncertain future. Industrial Relations Journal, vol. 37, no.5, pp. 513-542.

Taylor, F. W., 1911. The Principles of Scientific Management. New York: Harper and Brothers. Reprinted, 1967. W. W. Norton \& Company.

The Grattan Institute. 2011. Productivity: The lost decade, Paper presented to the annual policy conference of the Reserve Bank of Australia, HC Coombs Conference Centre, Kirribillii, Sydney, 15th-16th August 2011

Tortorella, G.L. and Fogliatto, F.S. 2014. Method for assessing human resources management practices and organizational learning factors in a company under lean manufacturing implementation. International Journal of Production Research, DOI: $10.1080 / 00207543.2014 .881577$

Ulrich, D. 1998. Delivering results: a new mandate for human resource professionals. Boston: Harvard Business Review

Wadell, W., and Bodek, N., 2005 The Rebirth of American Industry. New York: PCS Press.

Weick, K. E., and Sutcliffe, K. M. 2007. Managing the unexpected: resilient performance in an age of uncertainty. John Wiley \& Sons, Inc.

West, M. and Patterson, M. 1998. People power: The link between job satisfaction and productivity. CentrePiece, vol. 3, no 3, pp. 2-5.

White, R.E, Ojha, D, and Kuo, C.C., 2010. A competitive progression perspective of JIT systems: evidence from early US implementations, International Journal of Production Research, vol. 48, no 20, pp. 6103-6124 
Williamson, S. 2013. Bioeconomy in transition. Life Scientist. Available at: http://lifescientist.com.au/content/biotechnology/article/bioeconomy-in-transition-371176028 Wright, P.M. and Snell, S.A. 1998. Toward a unifying framework for exploring fit and flexibility in strategic human resource management. Academy of Management Review, vol 23, no 4, pp. 756-772

Yin, R. K. 2003. Case Study Research: Design and Methods. Thousand Oaks, California: Sage Publications.

Youndt, M. A., S. Snell, J. W. Dean, Jr., D. P. Lepak. 1996. Human resource management, manufacturing strategy, and firm performance. Academy of Management Journal, vol 39, no 4, pp. 836-866. 